I Pontifical Catholic University of Rio Grande do Sul (PUC-RS),

Postgraduate Program in Social Sciences, Porto Alegre, RS, Brazil

andre.salata@pucrs.br

André Salata'

\title{
INEQUALITIES AND THE BRAZILIAN NEW DEMOCRACY: INCOME DISTRIBUTION BETWEEN CLASSES IN RECENT DECADES
}

The final years of military government in Brazil were marked by a growing expectation that the transition to the democratic regime would be able - or sufficient - to eliminate the main problems afflicting Brazilian society, including poverty, corruption, violence, the quality and reach of public services, inflation, inequalities, and so on (Fausto, I994). However, the recent literature on Brazil - whether in Sociology, Political Science or Economics, or even the reports circulating in the mass media over recent years - contains strong evidence that, despite the advances achieved in some areas over the last thirty years, many challenges need to be met still for these expectations to become concrete. In this article, I focus specifically on the question of income inequalities, evaluating whether the labour-based income gap between classes in Brazil has shrunk over the last few decades and, if so, how these might be explained.

One of the most widely recognized aspects of Brazilian society is its high level of income inequalities, meaning that for many years the country has been ranked among those nations with the highest income disparities in the world (Barros et al., 200I). This phenomenon has already been - and continues to be - widely studied by the specialized literature, which has observed a strong tendency for these inequalities to be reproduced, a trend maintained for decades at a very high level. On the other hand, though still running at a high level, some measures of inequality have begun to fall over recent years. This is the case of the GINI coefficient, for instance, which has fallen continu- 
ously over the last decade, reaching the lowest values since it first started to be measured in the country (Barros et al., 20I0).

These more conventional measures of inequalities, like the GINI index, present a number of limitations, however, which will be discussed more closely over the course of the article. For now I simply observe that they lack the capacity to measure what have become known as 'enduring inequalities' (Tilly, I999): in other words, the kinds of structured and institutionalized inequalities that tend to be reproduced over the long term and are manifested between socially significant groups and categories. In this article, therefore, I shall analyse the income inequalities between classes - rather than individuals.

My interest resides in analysing the pattern of inequalities in labour income between classes in the period from I995 to 2013. Consequently, the starting point for this study will be the moment following stabilization of the currency (the Plano Real) and also political stabilization, namely the first year of the Fernando Henrique Cardoso government (PSDB), the first directly elected president after the military regime to conclude his mandate. The period analysed will cover the two mandates of the president elected from the PSDB (1995-2002) and also the more recent period of the governments of the PT, with the two mandates of Luiz Inácio Lula da Silva (2003-2010) and the first period of Dilma Rousseff (20I I-20I4) as head of the federal government. I therefore focus on the trends in the pattern of inequalities in some of the most important political periods since the return to democracy, when two of the most significant political parties active in Brazil, which have recently been the main rivals in the country's major political-electoral disputes, were in command of the federal government.

During this period we can identify distinct contexts and economic policies that without doubt had an impact on inequalities. Two moments can be highlighted: the first spans from the election of Fernando Henrique Cardoso (FHC) to the second half of the Luiz Inácio Lula da Silva (Lula) government and is marked by the concern with economic stability - sustained through measures like maintaining a primary surplus and high interest rates - by freezing or slight increases in the real value of the minimum wage and by a weaker economic performance; the second moment runs from the second half of Lula's first presidential mandate, with the reduction in interest rates, a reduction of the primary surplus, a real increase in the minimum wage and the expansion of credit. During this second phase, these measures were accompanied by higher rates of economic growth, a reduction in unemployment and poverty, and most importantly a substantial decrease in income inequality between individuals, which by the end of the 2000 s had reached the lowest levels of the historical series.

In terms of methodology, I used data from the National Household Sample Survey (PNAD) compiled by the Brazilian Institute of Geography and 
Statistics(IBGE), selecting the years from I 995 to 20I3. Applying the class schema developed by Valle Silva (I992) allows us to measure inequalities in income - derived from paid work - between the classes over the period under analysis.

The article is structured as follows: in the following section I provide a brief review of the literature on income inequality in Brazil, also citing the debate concerning the relation between inequalities and democracy. In the second section, I turn to examine the main critiques of the way in which income inequalities have normally been measured, and I present the class schema to be utilized, discussing its validity and main characteristics. The third section will explore the empirical data used to analyse class inequalities in Brazil over recent decades, specifically between I995 and 2013. Finally, in the conclusion, I look to relate the results obtained to the cited bibliography, and also search for possible explanations for the movements observed in the pattern of income inequalities and, moreover, identify potential responses to this question.

\section{INEQUALITIES AND DEMOCRACY}

Income inequality in Brazil has a lengthy history. Ever since reliable measures of inequalities began to be produced in the country, in the mid-twentieth century, the high level of income disparities became evident. As well as the accentuated level, however, our attention is also drawn to the persistence of these inequalities. When measured by the GINI coefficient (or by income ratios) using data from the Census or the PNADs, it can be seen that from the I96os, at least, inequalities have remained at high levels in the country with even higher trends observable during various different periods. From the I96os to I980s, for example, during periods of growth or economic crisis, therefore, we can observe an increase in inequality (Barros \& Mendonça, I995).

The expectation that the end of the military dictatorship and the transition to democracy would be sufficient to deal with some of the country's severest social problems, like poverty and inequalities, is supported by some of the literature on the topic (Ansell \& Samuels, 20I4). The argument presented by some authors is that by opening up the possibility for most of the population to take part - in some form, even if indirectly - in making decisions, democratic governments tend to raise social expenditure and distribute resources in more egalitarian fashion than autocratic governments.

This argument has very often been sustained by the familiar idea of the average voter. By extending political rights to the majority of the population, unequal societies like Brazil's will tend to have an average voter closer to the poorer sectors, which tend to support governments committed to higher social expenditure and redistribution policies. As a result, in order to appeal to these electors to maximize their votes, political parties in democratic environments 
will supposedly tend to back and implement redistributive measures more frequently.

As observed by Sen (200I), diverse kinds of inequalities are present in any society. In this sense, we can take democracy as an indicator of political equality and thus ask: is there a relation between political inequality and socioeconomic inequality? This question has been posed ever since Aristotle, in fact, and many authors have argued - as mentioned earlier - that in a democratic system the less privileged portion of the population will press for the transfer of resources controlled by the more privileged sectors (Bermeo, 2009). In other words, greater political equality will supposedly be accompanied by greater economic equality.

Many factors influence the distribution of incomes within the labour market, such as workforce shortages, the concentration of human capital, the level of technological development and so on. However, the market is embedded in a political context that can without doubt affect this distribution in diverse ways, making it more homogenous our heterogeneous, in accordance with the institutions and policies put into practice. The expectation is, therefore, that where political power is more widely distributed, as in democratic systems, the institutions and policies aim to distribute resources. In societies where political power is more heavily concentrated, though, we would expect the institutions and policies to work towards concentrating economic resources. This expectation is even stronger in societies with a high concentration of economic resources, since democratization - understood here as the extension of the right to vote to most of the population - is assumed to bring the average voter towards the poorest sectors, leading therefore to the assertion of redistributive policies (Meltzer \& Richard, I98I).

Empirical studies developed in recent years, however, have shown that the relation between democracy and inequalities seems much less simple, meaning that there is no consistent evidence that the above logic has actually prevailed. On the contrary, some works even show that democratic systems tend to concentrate resources rather than distribute them, and that no relation apparently exists between democracy and an increase in social expenditure. Some of the explanations for these findings turn on the possibility of powerful economic elites managing to control the political sphere (Mills, I999), influencing governments, parties and even voters. Other authors, though, question the assumed progressive tendency of poorer voters, arguing that in general these classes tend to be conservative. What the specialized literature, shows, therefore, is that we can never be sure concerning the effect of democracy on the distribution of economic resources (Acemoglu et al., 2013).

While we lack conclusive data concerning the effect of greater political equality on economic inequality, there are consistent findings on the potential political consequences of the distribution of economic resources. More specifi- 
cally, some degree of convergence exists concerning the deleterious effects of inequality on the quality of democracy. Some possible mechanisms could help us understand this relation better. In very unequal countries, the wealthiest can have a disproportional influence on electoral manoeuvring, on party programs, on the policies implemented by governments and so on, distorting the idea of representativeness. Some studies point to a negative relation between inequality, turnout at the voting booths and political engagement, showing that it can affect the interest in politics of a large portion of the population. Inequality can encourage political polarization and radicalization, possibly reducing mutual trust and the commitment to the rules of the democratic system, as well as increasing the tolerance of authoritarian measures and abuses of power, since it may undermine the solidarity between the different social classes.

As a result, democratic regimes in economically more unequal societies can show a decline in quality. Wilkinson and Pickett (20 I I), for example, present interesting data showing how more unequal countries tend to present higher levels of violence, imprisonment, worse indicators for physical and mental health among the population, lower life expectancy, poor educational performance and the like. Worse still, all these consequences in combination can reduce the legitimacy of and trust in the democratic institutions themselves. Indeed, studies on the theme indicate the following scenario: on one hand, democracy does not seem to have any clear effect on economic inequalities, in the sense of automatically favouring a better distribution of resources; on the other hand, a poor distribution of these resources can lead to a deterioration in the quality of the country's democracy and even jeopardize its continuity.

Taking the democratic context in Brazil over the last few decades as a background for the analysis, therefore, has the country seen a reduction in income inequalities? This question is important and necessary. Necessary because, as we have seen, democratic regimes do not automatically tend to distribute resources: rather, the relation is contingent. And important because more egalitarian societies tend to enjoy a better quality democracy.

Works like those of Barros et al. (200I) show that from at least the start of the Ig9os to the beginning of this century, what we see in Brazil is some degree of stability in the income inequalities between individuals without any clear downward trend - despite the pronounced annual variations between the end of the Ig8os and the start of the Ig9os, the outcome of the economic instability during the period. It is only from the previous decade that a clear and continuous downward trend in income inequalities has become evident, so that the GINI coefficient at the end of the last decade has attained the lowest points of its historical series for the country.

In this article, I ask to what extent there has been a decline in income inequality between classes over the years between I995 and 2013, and which classes have benefitted least and most? In the following section I present a 
number of arguments, based on the specialized literature, with the aim of measuring the inequality between classes rather than individuals.

\section{CLASSES AND INEQUALITIES}

In terms of income inequalities between individuals (or households), like those measured by the GINI coefficient or other correlate measures (income ratios, proportion of accumulated income, Theil index and so on), there is sufficiently strong evidence, analysed in important works (Barros et al., 20I0), that Brazil has recently seen a marked improvement in income distribution between individuals. However, income inequality can be measured not only by taking individuals as a unit of analysis, but also social categories or groups, such as inequality between countries, regions, states, genders, colour or race, economic sectors, classes and so forth (Medeiros, 2012).

Every measure of inequality has its own properties and measures this phenomenon in a specific way among the diverse possibilities. The GINI coefficient, for example, is more commonly used to measure inequality between individuals rather than categories. Like any other indicator, therefore, it involves a particular measure of inequalities, the outcome of a pre-established and non-universal theoretical approach. In this section I argue that if we wish to analyse the structural character of inequalities, undoubtedly very interesting from a sociological viewpoint, other ways of exploring the same phenomenon can be utilized.

Basically the paradigm of class analysis, adopted in this text, takes income distribution as a manifestation of the prior distribution of the resources that allow certain categories of individuals to obtain a lesser or greater proportion of the revenue. In this sense, the inequalities in physical well-being derive from what individuals have and what they do with what they have (Figueiredo Santos, 20I5). The distribution of these resources, in turn, is not random but institutionalized. For this reason, we can speak of categories of individuals, or classes, who control determined types of resources.

Two important contemporary sociologists, Goldthorpe (2009) and Wright (2005), assert that class-based analyses are fundamental to investigating the causal mechanisms that help to explain the localization of individuals in the distribution of resources. It is assumed, therefore, that the inequalities do not present a gradational distribution - in the form of a ladder (e.g. poor, middle class, upper class, etc.) - but a relational distribution, formed by a structure of interdependent classes (for example: unskilled manual workers, large employers, administrators and professional workers, etc.). From this perspective, inequalities are the outcome of structured and very often institutionalized relations, assumed by these classes, whether in the production process (Marx \& Engels, 2002), in the market (Weber, I978), or in social space (Bourdieu, 2008). 
The preference among sociologists for analysing inequalities through the idea of classes therefore stems from the importance that they attribute to the relations - structural and/or institutional - established by individuals (Hout, 2008). In this sense, classes are relevant since they allow individuals to be distinguished according to their life chances and thus enable analyses of enduring inequalities and their mechanisms of reproduction (Tilly, I999). As a result, the use of classes in studies of income inequality allows us to recognize the presence of structural fractures in the income distribution of the studied population, thereby correcting certain deficiencies found in the econometric models (Figueiredo Santos, 2005).

In Brazil, a huge debate exists on income inequality, seen from quite diverse perspectives (Langoni, I973; Fishlow, I972, I973; Ferreira, 2000; Barros et al., 200I; Valle Silva, 2003). Analysing the transformations occurring over recent years, however, we can observe the predominance of works, normally developed in the field of economics, that focus on income distribution between individuals, paying little attention to the sociostructural character of this distribution.

From a sociological viewpoint, though, I argue that it would be more interesting to analyse the inequalities between social groups defined through nominal categories like gender, race and, in this case, class situations. This is because inequalities between individuals can originate from an enormous range of factors, many of them irrelevant - such as luck, for example (Jencks, I973) - meaning that they tell us little about the possible changes in the structural pattern of inequalities (Valle Silva, 2003). In other words, the kind of analysis that has been carried out does not make it possible to know whether or not the recent transformations in income distribution in Brazil are, at least in part, a reflection of structural changes, more interesting and important from the sociological viewpoint.

Exploring this more structural dimension, the recent drop in income inequality between individuals may be the result of three distinct movements. The first possibility is an effect of composition with a change in the participation of the different classes in the socio-occupational structure. Since the classes differ in terms of their average incomes, a change in the participation of the classes may alter the distribution of incomes between individuals. The second possibility is the reduction in income inequalities within classes - that is, a reduction in the income gaps between individuals making up the different classes. Finally, the third possibility, the one that most interests us here, is the reduction of the distances between classes, such that the average incomes of the less privileged classes move closer to the wealthier.

In the present article I have no intention of measuring the extent to which each of these movements may have been responsible for reducing inequalities between individuals, nor of decomposing the income variations in 
order to ascertain the relevance of the between-group variation vis-à-vis intragroup variation - which was already conducted by other important studies (Souza et al., 20I4; Ribeiro et al., 20I4) - but only of verifying whether there has been a reduction in income inequalities between classes.

Setting out from the premise - backed by theory and also by important empirical studies carried out in the last few years - that analysing the movement of income inequality between classes is relevant, we can therefore ask: has this inequality in fact declined over recent years? If so, what changes can be observed, what classes benefitted most and which benefitted least?

\section{THE NVS SCHEMA}

In order to be able to access the more structural aspect of the inequalities, in this work I use the class schema developed by Nelson do Valle Silva (I992) as a proxy for class situations. Originally this schema had eighteen categories, but here I shall use their version aggregated into nine groups (Scalon, I 999): Professionals, Administrators and Managers, Employers/Owners, Non-Manual Routine Workers, Self-Employed Workers, Skilled Manual Workers, Unskilled Manual Workers, Rural Employers and Rural Workers.

Here I interpret the NVS schema through an approach that has been defined as CARs, an abbreviation for Capitals, Assets and Resources (Savage \& Devine, 2005). This contrasts with the now classic employment aggregate approach (Crompton, I998), placing less emphasis on the division of labour and concentrating on the mechanisms and effects through which classes are produced through the actions of individuals sustained by different capitals, resources or assets.

In other words, classes will be understood as aggregates of individuals who possess quantitative and qualitatively similar resources, which form the basis for their power to pursue their interests in the market. Classes, in this conception, concern the life chances conditioned by capacities and resources unequally distributed among the population.

Following part of the sociological tradition on this theme (Wright, I985; Butler \& Savage, I995), I shall interpret these resources via the idea of assets. Giddens et al. (I973) claim that in advanced societies three main types of resources (assets) exist that individuals can bring to the labour market: property, skills/qualifications and their labour power. In the table below I look to classify the nine categories in accordance with the degree to which this market situation depends on each of these assets: 


\begin{tabular}{l|c|c|c}
\hline Socio-Occupational Categories & Property & Skills/Qualifications & Labour Power \\
\hline Owners/Employers & $* * *$ & $*$ & - \\
\hline Administrators and Managers & $*$ & $* *$ & $* * *$ \\
\hline Professionals & - & $* *$ & $*$ \\
\hline Routine Non-Manual Workers & - & $*$ & $* * *$ \\
\hline Self-Employed Workers & $* *$ & $*$ & $* * *$ \\
\hline Skilled Manual Workers & - & - & $* * *$ \\
\hline Unskilled Manual Workers & - & - & - \\
\hline Rural Employers & $* * *$ & - & $* * *$ \\
\hline Rural Workers & - & & $*$ \\
\hline
\end{tabular}

Table I

Socio-occupational categories according to theirassets

Source: Author's own elaboration.

*** Many

** Average

* Few

- None

The table above is no more than a conceptual tool and has been included with the aim of helping us to reflect on the socio-occupational categories that we are using. There are some categories whose market power depends heavily on property. This is the case principally of the Owners/Employers and Rural Employers. Self-Employed Workers, despite being owners (without employees), are largely supported by their own labour power, as attested by some of the occupations that we most typically encounter in this category, including vendors selling from stores, kiosks and stalls, waiters, bar staff, butlers and so on.

The main resource of other categories is found in their qualifications and skills, the Professionals being the most typical case. In addition to these groups, we also have the Administrators and Managers. The latter category is the most difficult to analyse since it involves a group formed mostly by employees with average/high levels of education, whose main asset is undoubtedly their qualifications. But by performing functions related to authority and the control and management of property - despite not typically being owners - they can also be considered dependent on property as an asset. Since they are also generally employees, Professionals, Administrators and Managers also depend to some extent on their labour power.

Finally we have the categories whose main resource is their labour power, like the Rural Employees, the Non-Manual Routine Employees - who 
also depend on their qualifications, through which they manage to escape manual jobs with less prestige - the Unskilled Manual Workers and the Skilled Manual Workers. In the case of the latter, given the importance of their qualifications, which very often guarantees them work and returns above those of unskilled workers, we can also consider the importance of skills for their chances in the labour market.

The question posed in this text is: within the democratic context over the last few decades, can we observe the decline in income inequalities between classes in Brazil? If so, which classes have benefitted most and which have benefitted least? In the next section I seek to reply to this question through an analysis of the empirical data.

\section{CLASSES AND INCOMES BETWEEN 1995 AND 2013}

For these empirical analyses, I shall use the data from the National Household Sample Survey (PNAD-IBGE). It is true that the income from the richest is underrepresented in the PNADs, especially those with the $5 \%$ and/or $\mathrm{I} \%$ highest incomes in the country, which skews downward the level of inequalities measured, interfering significantly in the analyses of inequalities.

At the same time, it is also true that, despite this known flaw in measuring the income of the richest sector, the PNAD remains an extremely useful and interesting tool for examining income inequalities in the country. Even using 'just' PNAD data, the enormous income inequality in Brazil is clear and evident, such that the figures generated through the survey place the country (for decades) among the most unequal in the world. The fact that PNAD does not adequately measure the income of the most wealthy (despite capturing a sizeable fraction), as we shall see, does not rule it out from observing some extremely important movements, including the distribution of incomes, that have occurred in the heart of the Brazilian population.

The time period studied here spans between 1995 and 2013. As stated earlier, this period covered allows us to include the two mandates of Fernando Henrique Cardoso (PSDB) between I995 and 2002, the two mandates of President Luiz Inácio Lula da Silva (PT) between 2003 and 2010, and almost the entire first period of his successor, Dilma Roussef (PT), as President of the Republic between 20I I and 2014 .

In geographic terms, it was necessary to remove households located in rural areas of Brazil's North from the analysis, given that IBGE only began to collect this data from 2004 onward. In relation to the individuals included in my sample, I shall work only with those aged ten years or more. In addition, as we only have precise information on the occupation of those individuals who were employed in the week of reference of the surveys, the sample employed here will be limited to the employed population. 
On the occupational data from the PNAD, which serve as the starting point to the creation of the socio-occupational categories used in this work, it is important to recall that a change took place in the classification system used by the Brazilian Institute of Geography and Statistics (IBGE). From 2002 the IBGE has adopted the Brazilian Classification of Occupations (CBO) in the PNADs. As a consequence, some adaptations had to be made in order for it to be possible to maintain compatibility between the years under study.

It is important to make clear that in this article the focus is merely on the income from labour, based on the fact that previous studies have shown that much of the distribution taking place over recent years occurred in the sphere of the labour market.

The main question examined here will be the relation over the last few decades between the nine socio-occupational categories, used as proxies for class situations, and the monthly gross incomes from the main work. It is important to recall that this data concerns solely monetary income, leaving out non-monetary or unattributable income. In addition, I decided to exclude the cases where information was missing or with null income (equal to zero), since this information in general is fairly unreliable and ends up introducing undesired distortions to the analysis (Valle Silva, 2003). It should also be noted that for employers and the self-employed, the information refers to the monthly withdrawal normally made or, when the income was variable, to the average monthly withdrawal. In the case of those employed in the primary sector, the income in money and the real or estimated value of the produce occasionally received as payment for their work were also studied.

Graph I displays the average income from the main work for each of the occupational categories between I995 and 20I3. This graph clearly shows the income inequality between some of the socio-occupational categories. It can be seen that we have a first group with incomes much higher than the others, formed by the Owner/Employers, the Professionals, the Administrators and Managers and the Rural Employers. The average income for these categories in 2013 was between $\mathrm{R} \$ 4,665$ (Owners/Employers) and $\mathrm{R} \$ 3$, I 8I (Administrators and Managers). Meanwhile the lower part of the graph shows another group, formed by categories with much lower average incomes: Self-Employed Workers, Routine Non-Manual Workers, Skilled Manual Workers, Unskilled Manual Workers and Rural Workers. In this second group the average income in 2013 varied between R\$I,576 (Self-Employed Owners) and R\$939 (Rural Workers).

These results make evident the main structural gap in terms of income, which clearly separates the classes whose main assets are property and schooling from those whose main resource is their labour power. The former clearly show averages systematically higher than the others, which can be readily observed in the above graph. Furthermore, it can also be perceived that the same logic applies internally to this group to their disadvantage. The class- 
es that possess other resources beside their labour power (education/skills or property), like the Routine Non-Manual Workers and the Self-Employed, obtain income consistently higher than the others. Consequently the lower average incomes are found among the Unskilled Manual Workers and Rural Workers, who rely exclusively on their labour power. What most interests us here, however, is the slope of the lines, which graphically indicates variations in the average incomes between the years for each of the categories. In this sense, the fairly expressive growth in average income for Rural Employers stands out sharply, especially after $20 \mathrm{II}$, when the value was $\mathrm{R} \$ 4,3 \mathrm{I} 8$, rising to $\mathrm{R} \$ 7$, IO 8 in 20I3. Variations of this magnitude, in such a short space of time, are fairly improbable, meaning that they may be largely the result of sample error. The category has very few cases - in 2013 there were just 4 I 6 individuals in this category in the PNAD sample - and with a standard deviation of average income that jumped to values over R $\$ 15,000$ in 2012 and 20I3. For these reasons, I think it is pertinent to ignore the variation in average income for this category over recent years.

Among the other categories, the pattern shown is a decline in average incomes between 1996 and 2004 and, thereafter, a clear upward trend, with a variable intensity between the categories. In absolute terms, as shown in Graph I, the categories with higher incomes are those whose earnings were in general higher in the period analysed. For example, while the average income of Unskilled Manual Workers jumped from $\mathrm{R} \$ 657$ in 2002 to $\mathrm{R} \$ \mathrm{I}, \mathrm{OII}$ in 2013, among Professionals it rose from $\mathrm{R} \$ 4,073$ to $\mathrm{R} \$ 4,665$. The income disparities - that is, the absolute differences between the averages - seem to have increased over recent years.

Inequalities, however, differently to disparities, are normally measured in relative rather than absolute terms. As we shall see below, when we examine these variations in proportional terms, it seems that it was the lower categories that gained most in recent years.

Graph 2 shows the average annual variation in incomes, in percentage points, for each of the socio-occupational categories. As can be seen in the horizontal axis of the graph, the averages were calculated for three distinct periods: the first years, from I 995 to 2002; the later years, from 2003 to 2013; and the period as a whole, from I995 to 2013. This division was made for two main reasons. The first is that, as we saw in Graph I, there is a clear variation in the general trend of income averages over the entire period, with a downward trend until mid-2003 or 2004, and an upward trend thereafter, in line with the macroeconomic cycles. The second reason is political rather than economic in kind, and concerns the distinction between the periods when the PSDB and PT headed the federal government. I should make it clear, however, that it is not a case here of any simplistic attempt at comparison, since many variables (economic cycles, external environment, etc.) can influence the ob- 


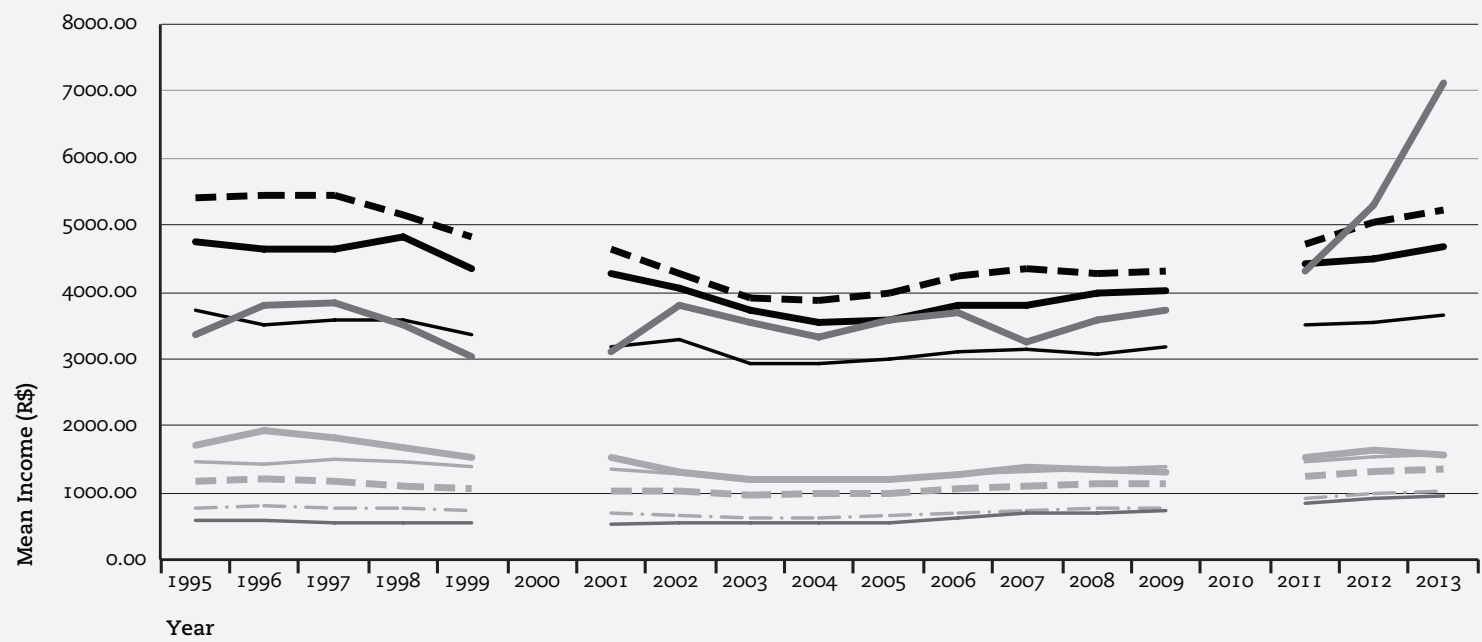

- Owners/Employers

Professionals

Administrators and Managers

Self-Employed Workers

r Routine Non-Manual Workers

- Skilled Manual Workers

_-. Unskilled Manual Workers

Rural Employers

— Rural Workers

Graph I

Average monthly incomes* from the main work by socio-occupational categories

Brazil, I995-2013

Source: PNAD, I995-20I3 (IBGE). Author's tabulations.

* Constant prices: incomes deflated by INPC for 28 September 2014

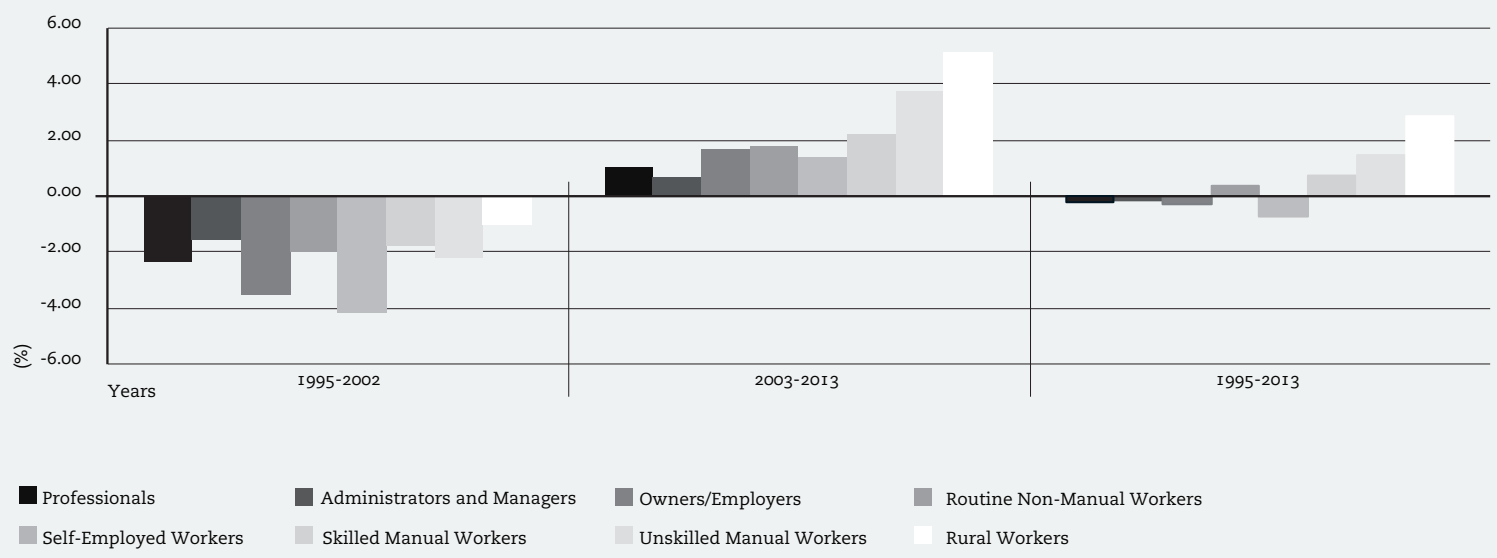

Graph 2

Average annual variation in monthly incomes* from the main work, by socio-occupational categories, ${ }^{* *}$ in percentage points

Brazil, I995-2013

Source: PNAD, I995-20I3 (IBGE). Author's tabulations.

* Constant prices: incomes deflated by INPC for 28 September 2014

** Rural Employers were excluded from the analysis. 
served trends, and also because measures adopted by one government may have an effect only (or also) in later periods.

Looking at the series more to the right, we can observe that not all the categories showed averages with positive variation in the last decades, specifically between I995 and 2013. While Rural Workers, Unskilled Manual Workers, Skilled Manual Workers and Routine Non-Manual Workers showed a positive balance in the average annual variation of incomes in percentage points, Self-Employed Workers, Owners/Employers, Administrators and Managers, and Professionals, had a negative balance during the period. We can see, therefore, that during the period as a whole, the categories that proportionally seem to have obtained the best results were precisely those that present lower income averages. Among them, moreover, it was the Rural Employees and Unskilled Manual Workers, the two categories with the lowest incomes, which on average showed higher annual increases in percentage points.

Further to the left, though, we can see that the trends observed for the period as a whole result from two very distinct moments. In the first period, between I995 and 2002, all the categories present a negative balance, especially the Self-Employed and Owners/Employers. In the second period, though, between 2003 and 2013, all the classes present a positive balance, principally the workers (Rural Employees, Unskilled Manual Workers and Skilled Manual Workers). Some of the categories with higher categories, for their part, like the Professionals, Administrators and Managers, present the lowest averages of annual variation in percentage points between 2003 and 2013. In fact, while the income of the Professionals varied on average by $1.00 \%$ between 2003 and 2013, among the Unskilled Manual Workers this average variation was $3.72 \%$.

Hence, it was the classes whose main asset is their labour power which showed the highest proportional income gains in recent years. At the other end, those categories whose most important resource is either property or schooling, showed the lowest proportional gains. I return to this point later, in the conclusion. As a result of these differentials in the percentage variations in income, given that those categories with the lowest absolute averages showed the highest proportional gains, inequality in income between the categories has shown a downward trend over recent years, as can be verified in Graph 3.

Graph 3 displays the ratios of the income averages for the classes between I995 and 2013, taking the category of Unskilled Manual Workers as a baseline. The first point to highlight is the advantage that some categories have over others. In 2005, the average income of Owners/Employers was almost 7 times greater than that of Unskilled Manual Workers. The same measure was more than 6 times higher for Professionals, and 4.8 times higher for Administrators and Managers. Once again we can observe the enormous gap separating these categories from workers in general. Lower down we can see that in I 995 


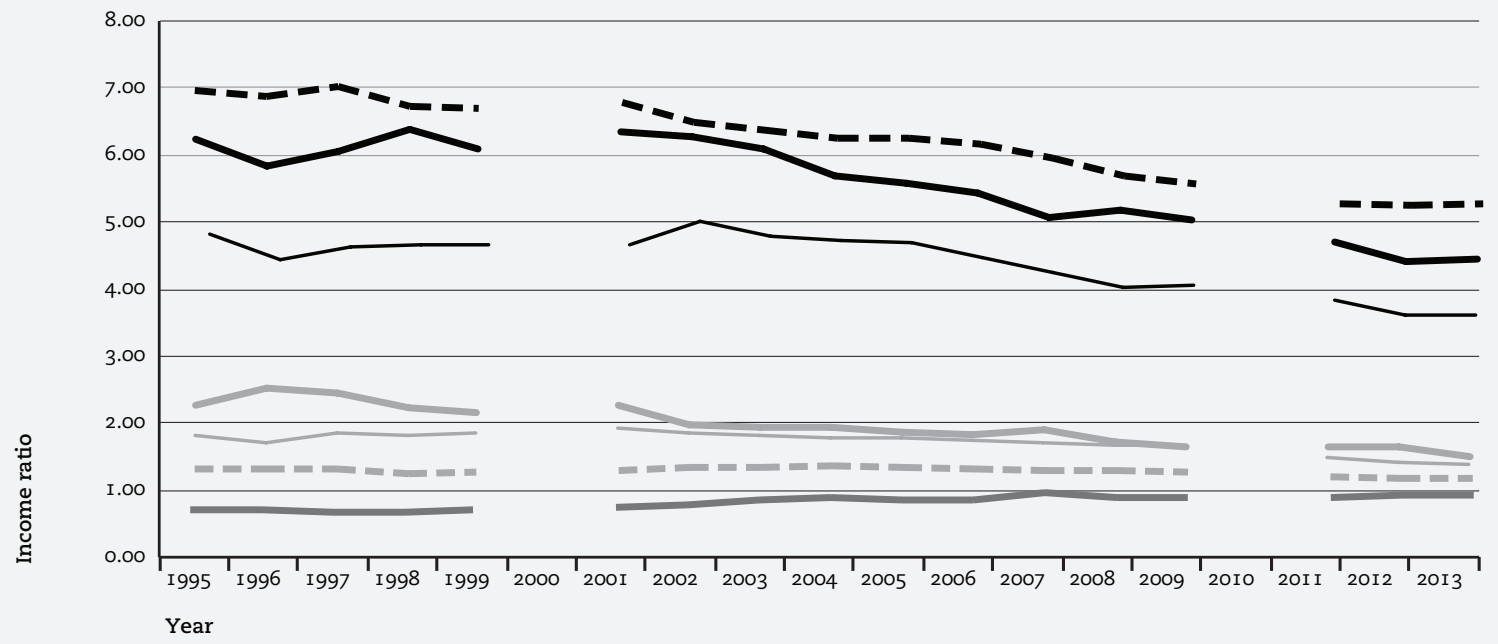

\section{Self-Employed Workers}

Routine Non-Manual Workers
- Skilled Manual Workers

Rural Workers

Administrators and Managers

Graph 3

Ratios of income averages* by socio-occupational categories** Brazil, I995-20I3 $3^{* * *}$

Source: PNAD, I995-20I3 (IBGE). Author's tabulations.

* Constant prices: incomes deflated by INPC for 28 September 2014.

** Base category: Unskilled Manual Workers.

*** Rural Employers were excluded from the analysis. 
the Self-Employed Workers, Routine Non-Manual Workers and Skilled Manual Workers has an average income between one and a half and two and a half times the value of the average for the Unskilled Manual Workers. The average of the Rural Workers, for their part, was 0.74 times the average of the other category.

While we can note the existence of inequalities within these two groups of classes (upper and lower), the enormous gap between them is notable, separating the class of workers (in the lower section) from the others (in the upper section, with the higher averages). It is also worth noting that these gaps presented stability, since the general structure has been maintained over the last decades. On the other hand, I cannot fail to mention - and this perhaps is the point to be emphasized in Graph 3 - some important changes during the period analysed.

The information provided above, graphically represented by the slope of the lines, indicate a clear downward trend in the amplitude of the income inequalities between the socio-occupational strata from 2001/2002 onward. ${ }^{\text {I }}$ Obviously, as a category with one of the lowest incomes was taken as a baseline, this also presented one of the highest gains over the period, as expected. However, it is important to stress that even if we use other lower strata has a baseline, whether the Skilled Manual Workers or Rural Workers, the results would be similar, since it was among these categories that the highest proportional income gains were verified.

We can see, therefore, that the income ratio in 2013 fell to 5.1 in the case of Owners/Employers, 4.6 in the case of Professionals and 3.6 in the case of Administrators and Managers. Basically, what we observe from the first years of this century is a decline in the important gap separating the categories of workers from the others. There was, therefore, a reduction of this striking gap over recent years, despite the gap remaining still at a fairly high level.

It is interesting to observe that there has also been a reduction in the gaps between the lower classes, whose respective lines are visibly closer in the recent period. In the case of Rural Employees, for example, in 2013 their income already corresponded to 0.93 times the average income of the Unskilled Manual Workers. For Skilled Manual Workers, this measure remained at I.33, and in the case of the Self-Employed and Routine Non-Manual Workers hovered around I.5. ${ }^{2}$ Once again, however, I emphasize that the most important point is that in recent years there was a reduction in the income inequalities between the classes whose main asset is their labour power and those whose most important resource is either schooling or property. 


\section{CONCLUSION}

Thirty years ago Brazil elected, albeit indirectly, its first civil president since the military dictatorship took power in I964. This was a landmark in the country's transition to the new Brazilian democracy. In the wake of this movement, a huge expectation led part of the population to believe that the country's main problems would be 'naturally' resolved after the re-establishment of the democratic regime. Thirty years later, though, we can see that the relation between democracy and confronting the enormous social problems that afflict the country is much more complicated. In this article, in particular, I focused on what can be considered one of the main problems of Brazilian society: its high level of income inequalities. My question, therefore, was whether there had been a reduction in income inequalities between classes over recent decades, from the beginning of the first mandate of Fernando Henrique Cardoso (PSDB) in I995, to the final years of the first period of Dilma Rousseff (PT) as president, including of course the two mandates of Luiz Inácio Lula da Silva (PT).

Through empirical analyses using data on the Brazilian population between I995 and 2013, firstly I ascertained whether there had been an absolute increase in incomes for all categories over recent years. ${ }^{3}$ However, despite all the classes having benefitted from this income increase from 2001/2002 onward, in proportional terms the categories that presented the highest increases in their incomes were those whose main asset was labour power, like Skilled Manual Workers, Unskilled Manual Workers and Rural Workers. On the other hand, the classes that had less proportional gains were those whose main assets were qualifications/skills and/or property - like Professionals, Owners/ Employers and Administrators and Managers.

Hence the data presented in this article lend support to the idea of a reduction in inequalities between classes, such that in recent years the working classes presented the highest gains, while the middle classes ${ }^{4}$ had the lowest proportional income gains. This is, without any doubt, an extremely important observation in terms of a better understanding of the dynamic that led to the recent decline in inequalities.

According to the recent literature on the theme, the causes of these movements probably centre around three key factors: valorisation of the minimum wage (which became intensified from 2004), a reduction in unemployment (which from 2005 began a clear downward trend), and an increase in the population's schooling (a long-term trend). ${ }^{5}$

Despite remaining a controversial question, in recent years some works have sustained the hypothesis that rises to the minimum wage tend to affect workers with lower income more strongly (Menezes-Filho et al., 2009; Soares, 2002). The recent increase in levels of schooling, in turn, seems to have reduced educational inequalities and thus also income inequalities (quantity effect), but 
also reduced the premium - in income etc. - of those categories with higher educational qualifications (price effect) (Barros et al., 2007). Finally, it may well be that the greater demand for labour power, translated in lower unemployment rates, has helped drive up workers' salaries (Pochmann , 20I4; Ramos, I99I). ${ }^{6}$ Factors endogenous to the market and institutional elements can both, therefore, help us explain why Brazil has recently witnessed a reduction in inequalities between classes.?

Beyond its more immediate importance in the recent debate on the decline in income inequalities in Brazil, the findings obtained here are relevant for two other reasons. First, they show the advantages of using the idea of classes to think about inequalities. Different economic classes respond to variations in the political and economic contexts in distinct ways, such that, depending on the resources at their disposal, these variations may be to their advantage or disadvantage. Paying attention to class divisions is thus essential to a better comprehension of the dynamic of inequalities. Second, while these findings can be taken as fresh evidence that the relation between democracy and inequalities is far from simple, they also lend support to the idea that democracy creates new possibilities for combating structural inequalities even in a country like Brazil where the latter were - and still are - at very high levels.

The recent literature on inequalities has tended to agree on the hypothesis that, beyond economic development or types of political system per se, it is through political will, or more precisely through the play of forces present in a society, that we find the main causes for the great variations in resource distribution (Wilkinson \& Pickett, 20I I; Atkinson, 20I5). It is to be hoped, therefore, that efforts will continue to be made over the following decades to reduce the still high level of inequalities present in Brazil. Only then will we be able to enjoy a healthy democracy in the full sense of the term. 
André Salata is Professor of Sociology of the Graduate Program in Social Sciences at the Pontifical Catholic University of Rio Grande do Sul (PUCRS). Holding a PhD in Sociology from the Graduate Program in Sociology and Anthropology at the Federal University of Rio de Janeiro (PPGSA-UFRJ), his researches focus on social stratification and inequalities, working primary with quantitative methodologies. Author of Quem é classe média no Brasil? Um estudo sobre identidades de classe (20I5); The formation of the middle class in Brazil: history and prospects, co-authored with Celi Scalon (2013); and Desigualdades digitais: acesso e uso da Internet, posição social e segmentação espacial nas metrópoles brasileiras, co-authored with Luiz Cesar de Queiroz Ribeiro and Lygia G. Costa (2013). 


\section{NOTES}

I Following the Weberian tradition of studies of stratification, we take class to be a market position - that is, groups of individuals who share a similar market situation. As is common practice in the literature on stratification, we take occupational categories as proxy for classes. Over the course of the text, therefore, when 'class' is mentioned, I am referring to 'economic classes' in the Weberian sense. These will be operationalized through occupational categories in my analysis of the empirical data. For a more detailed and accessible exposition of this concept and its application, see Scalon (I999).

2 This article forms part of a wider research program conducted by the Brazilian Centre of Research in Democracy (CBPD) of the Pontifical Catholic University of Rio Grande do Sul (PUC-RS). In commemoration of the thirty years since the I985 election, a landmark moment in the transition to democracy, the Centre's researchers have sought to analyse the changes experienced by Brazilian society since then.

3 According to Barros et al. (2010), the GINI index for per capita family income in Brazil fell from 0.593 to 0.552 between 200 I and 2007.

4 As we shall see, it is not a question here of contesting the use of GINI and its admirable capacity to measure a particular type of inequality, but of remembering that this complex phenomenon, inequalities, can be analysed in diverse ways, meaning that the GINI coefficient is incapable of accounting for all of them.

5 Brazilian Social Democracy Party.

6 Partido dos Trabalhadores (Workers' Party).

7 See Singer (2012).

8 A more detailed analysis could obviously distinguish more than two periods.

9 During the first period, the overall trend was for the inequalities measured by GINI to be maintained.

Io Pesquisa Nacional por Amostra de Domicílios.

I I Instituto Brasileiro de Geografia e Estatística.

I 2 Remembering that PNAD was not carried out in 2000 and 2010 due to realization of the national Census. 
I3 Here I take 'democracy' in a narrow sense, referring to a method or institutional system for political decision making in which individuals have decision-making power through free competition for the votes (also free) of the electors (Schumpeter I950). The implied sense, therefore, is indirect representation through elections where the bulk of the population has the right to vote. This is not the only possible meaning of democracy, of course.

I4 The term 'socioeconomic inequality' can assume a myriad of meanings. In this article I am interested only in the inequalities of conditions (rather than opportunities), especially inequality of income from labour.

I5 It is not my intention in this article to enter directly into this important debate, only to approach it for a better understanding of the possibilities afforded by the conjuncture represented by the period under analysis. For a more in-depth discussion, consult the bibliography cited in the above paragraphs.

I6 The same cannot be said about the relation between equality and the probability of transition to democracy (Ansell \& Samuels 20I4).

I7 For a more complete review and bibliographic suggestions, see Bermeo (2009).

I 8 Though it may be applied in other ways.

I9 One of the great pluses of the GINI coefficient, like the Theil coefficient, is its capacity to summarize information on a distribution in a single value. At the same time, though, this could be considered one of its deficiencies, since we lose a lot of information, which is excessively summarized, when we analyse inequalities through these coefficients only.

20 However we could extend these arguments to gender, colour or race, etc.

2I Some recent exceptions are the works of Figueiredo Santos (2015, 2002), Valle Silva (2003) and Souza \& Carvalhaes (2014).

22 One possibility does not exclude the others, such that they can occur concomitantly. 
23 Valle Silva (I992) calls this category 'Self-Employed Owners' but here I use the term 'Self-Employed Workers.'

24 In order to group occupations in the 8 categories, Valle Silva (1992) adopted as a criterion the uniformity of market and labour positions, taking into consideration too the distinction between rural and urban contexts, the manual and non-manual sectors, and the separation between service sectors (tertiary) and industrial sectors (secondary); the latter was divided into modern industries and traditional industries. Later, Scalon (I999), studying patterns of mobility in Brazil, aggregated the eighteen original categories into just nine - as described in Table 2 in the appendix.

25 The idea of assets has been used both by authors closer to the neo-Marxist camp - as in the case of Erik Olin Wright - and by authors more aligned with a neo-Weberian perspective (Giddens et al., I973). The main difference between these two camps resides in the fact that the former examines the assets employed in the production process, while the latter focuses on the resources used in the market (Wright, I996). The approach adopted in this work is closer to the latter conception.

\section{BIBLIOGRAPHY}

Acemoglu, Daron; Naidu, Suresh; Restrepo, Pascual \& Robinson, James A. (2013). Democracy, redistribution and inequality. National Bureau of Economic Research. Working Paper $n^{\circ}$ I 9746. Available at:<http://www.nber.org/papers/wi 9746>. Accessed or/26/20I6.

Ansell, Ben W. \& Samuels, David J. (20I4). Inequality and democratization: an elite-competition approach. Cambridge: Cambridge University Press.

Atkinson, Anthony B. (20I5). Inequality: what can be done? Harvard: Harvard University Press.

Barros, Ricardo Paes; Carvalho, Mirela; Franco, Samuel \& Mendonça, Rosane. (20I0). Determinantes da queda na desigualdade de renda no Brasil. IPEA - Textos para Discussão, I460.

Barros, Ricardo Paes; Franco, Samuel \& Mendonça, Rosane. (2007). A recente queda na desigualdade de renda e o ace- 
lerado progresso educacional brasileiro da última década. IPEA - Textos para Discussão, I304.

Barros, Ricardo Paes; Henriques, Ricardo \& Mendonça, Rosane. (200I). A estabilidade inaceitável: desigualdade e pobreza no Brasil. IPEA - Textos para Discussão, 800.

Barros, Ricardo Paes \& Mendonça, Rosane. (I995). Os determinantes da desigualdade no Brasil. IPEA - Textos para Discussão, 377. Bermeo, Nancy. (2009). Does electoral democracy boost economic equality? Journal of Democracy, 4/20, p. 2 I-35.

Bourdieu, Pierre. (2008). A distinção: crítica social do julgamento. São Paulo: Edusp.

Butler, Tim. Savage, Mike (eds.). (I995). Social change and the middle classes. London: Routledge.

Crompton, Rosemary. (I998). Class and stratification: an introduction to current debates. 2a. ed. London: Polity Press.

Fausto, Boris. (I 994). História do Brasil. São Paulo: Edusp.

Ferreira, Francisco. (2000). Os determinantes da desigualdade de renda no Brasil: luta de classes ou heterogeneidade educacional? Rio de Janeiro: PUC-Rio.

Figueiredo Santos, José Alcides. (2015). Classe social e deslocamento de renda no Brasil. Dados - Revista de Ciências Sociais, 48/I, p. 79-I IO.

Figueiredo Santos, José Alcides. (2005). Efeitos de classe na desigualdade racial no Brasil. Dados - Revista de Ciências Sociais, 48/I, p. 2I-65.

Figueiredo Santos, José Alcides. (2002). Estrutura de posições de classe no Brasil: mapeamento, mudanças e efeitos na renda. Belo Horizonte/Rio de Janeiro: Ed. UFMG/Iuperj.

Fishlow, Albert. (I973). Distribuição de renda no Brasil: um novo exame. Dados - Revista de Ciências Sociais, I I, p. Io-80.

Fishlow, Albert. (1972). Brazilian size distribution of income. American Economic Review, 62/2, p. 391-402.

Giddens, Anthony; Ociepka, Franciszek \& Zujewicz, Wiktor. (I973). The class structure of the advanced societies. London: Hutchinson.

Goldthorpe, John H. (2009). Analyzing social inequality: a critique of two recent contributions from economics and epidemiology. European Sociological Review, 26/6, p. 73 I-744. 
Hout, Michael. (2008). How class works: objective and subjective aspects of class since the I970s. In: Lareau, Annettte \& Dalton, Conley (eds.). Social class: how does it work? New York: Russell Sage Foundation, p. 25-64.

Jencks, Christopher. (1973). Inequality. London: Allen Lane.

Ramos, Lauro. (I99I). Educação, desigualdade de renda e ciclo econômico no Brasil. IPEA - Textos para Discussão, 2 I 9.

Savage, Mike; Warde, Alan \& Devine, Fiona. (2005). Capitals, assets, and resources: some critical issues. The British Journal of Sociology, 56/I, p. 3I-47.

Sen, Amartya. (200I). Desigualdade reexaminada. São Paulo: Record.

Langoni, Carlos Geraldo. (2005). Distribuição da renda e desenvolvimento econômico do Brasil. Rio de Janeiro: FGV Editora.

Marx, Karl \& Engels, Friedrich. (2002). The Communist Manifesto. London: Penguin.

Medeiros, Marcelo. (2012). Medidas de desigualdade e pobreza. Brasília: Editora UnB.

Medeiros, Marcelo; Souza, Pedro H. G. \& Castro, Fabio Avila (20I5). O topo da distribuição de renda no Brasil: primeiras estimativas com dados tributários e comparação com pesquisas domiciliares (2006-20I2). Dados - Revista de Ciências Sociais, 58/ I, p. 7-36.

Meltzer, Allan M. \& Scott, Richard F. (I98I). "A rational theory of the size of Government. Journal of Political Economy, 89, p. 9I4-927.

Menezes-Filho, Naercio \& Rodrigues, Eduardo Augusto de Souza. (2009). Salário mínimo e desigualdade no Brasil entre I 98 I - I 999: um abordagem semiparamétrica. Revista Brasileira de Economia, 63/3, p. 277-298.

Mills, C. Wright. (I 999). The power elite. Oxford: Oxford University Press.

Pochmann, Marcio. (20I4). O mito da grande classe média: capitalismo e estrutura social. São Paulo: Boitempo Editorial.

Ribeiro, Carlos Antonio Costa; Barbosa, Rogério; Souza, Pedro Ferreira \& Carvalhaes, Flávio. (20I4). Os impactos da geração de empregos sobre as desigualdades de renda: uma análise da década de 2000. Revista Brasileira de Ciências Sociais, 29, p. 79-98. 
Scalon, Celi. (I999). Mobilidade social no Brasil: padrões e tendências. Rio de Janeiro: Revan.

Schumpeter, Joseph Alois. (I950). Capitalism, socialism, and democracy. Nova York: Harper.

Scott, John. (1996). Stratification \& power: structures of class, status and command. Cambridge: Polity Press.

Soares, Sergei Suarez Dillon. (2002). O impacto distributivo do salário mínimo: a distribuição individual dos rendimentos do trabalho. IPEA - Textos para Discussão, 873

Souza, Pedro Herculano Guimarães Ferreira \& Carvalhaes, Flavio Alex de Oliveira. (20I4). Estrutura de classes, educação e queda da desigualdade de renda (2002-20I I). Dados - Revista de Ciências Sociais, 57/I, p. IOI-I 28.

Singer, André. (20 I 2). Os sentidos do lulismo. Rio de Janeiro: Companhia das Letras.

Tilly, Charles. (I999). Durable inequality. Los Angeles: University of California Press.

Valle Silva, Nelson do. (2003). Os rendimentos pessoais. In: Hasenbalg, Carlos \& Valle Silva, Nelson (eds.) Origens e destinos: desigualdades sociais ao longo da vida. Rio de Janeiro: Topbooks, p. 43I-456.

Valle Silva, Nelson do. (I992). Uma Classificação Ocupacional para o Estudo da Mobilidade e da Situação de Trabalho no Brasil. Rio de Janeiro, Iuperj, mimeo.

Weber, Max. (1978). The distribution of power within the political community: Class, status, party. In: Economy and society. Oakland: University of California Press, p. 926-940 (vol. 2).

Wilkinson, Richard \& Pickett, Kate. (20I I). The spirit level: why greater equality makes societies stronger. London: Bloomsbury Publishing.

Wright, Erik. Olin. (1985). What is middle about the middle class? In: Roemer, John (ed.). Analytical Marxism. Cambridge: Cambridge University Press, p. I I4-I40.

Wright, Erik Olin. (198I). The continuing relevance of class analysis - comments. Theory and Society, 25/5, p. 693-7I6.

Wright, Erik Olin. (2005). If "Class" is the answer, what is the question? In Wright, Erik Olin (ed.) Approaches to Class Analysis. Cambridge: Cambridge University Press, p. I80-I92. 


\section{APPENDIX}

\begin{tabular}{|c|c|}
\hline Aggregated Categories & Original categories \\
\hline I- Professionals & $\begin{array}{l}\text { Professionals } \\
\text { Liberal Professionals }\end{array}$ \\
\hline 2- Administrators and Managers & $\begin{array}{l}\text { High-level directors and administrators } \\
\text { Employees in administrative posts }\end{array}$ \\
\hline 3- Owners/Employers & Owners/employers in industry, commerce and services \\
\hline 4- Routine Non-Manual Workers & $\begin{array}{l}\text { Routine non-manual and office work } \\
\text { Technicans, artists and supervisors of manual work }\end{array}$ \\
\hline 5- Self-Employed Workers & Self-employed (no employees) \\
\hline 6- Skilled Manual Workers & $\begin{array}{l}\text { Manual workers in modern industries } \\
\text { Manual workers in service industries }\end{array}$ \\
\hline 7- Unskilled Manual Workers & $\begin{array}{l}\text { Manual workers in traditional industries } \\
\text { Domestic workers }\end{array}$ \\
\hline
\end{tabular}

Table 2

Aggregated socio-occupational categories, following the original categories

Source: Author's elaboration. 


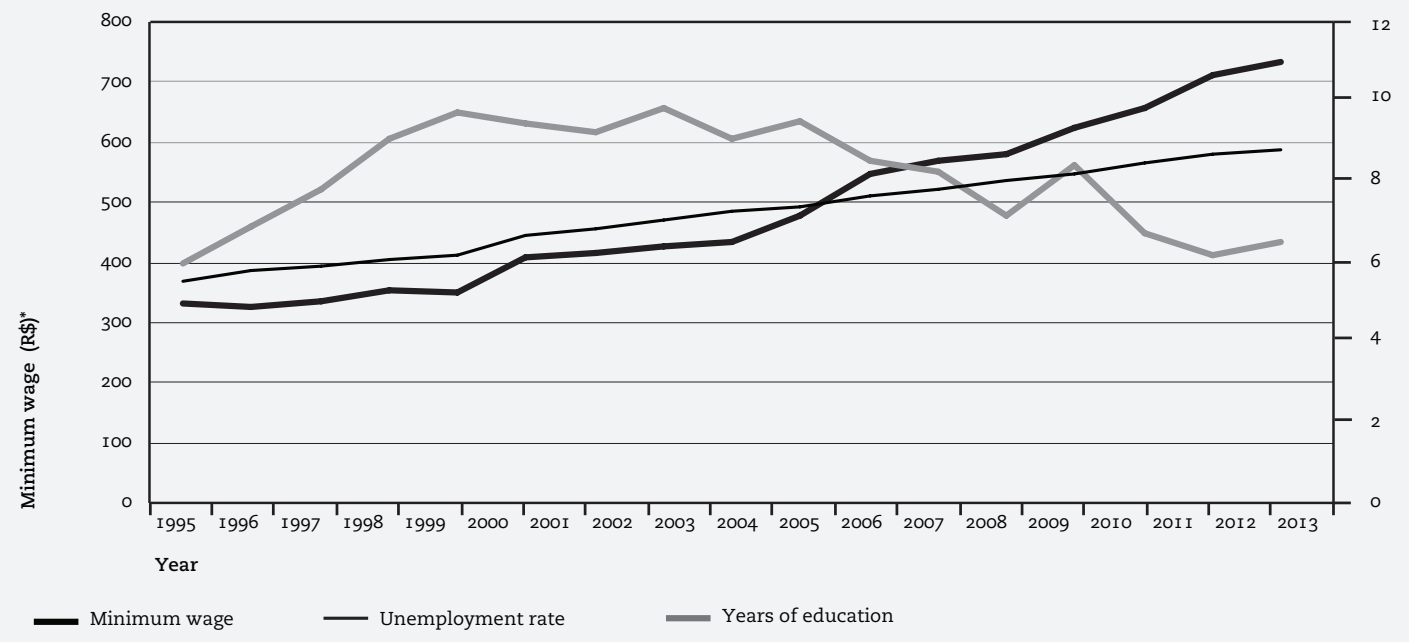

Graph 4

Evolution of the minimum wage*, Unemployment rate** and Average Schooling***

Brazil, I995-2013 $3^{* * * *}$

Source: PNAD, 2002-20I3 (IBGE). Author's tabulations.

* Constant prices (2014) - INPC.

** For people aged Io years or more.

*** For people classified as 'employed.'

**** Excluding rural areas of the North Region. 


\section{DESIGUALDADES E A NOVA DEMOCRACIA BRASILEIRA: A DISTRIBUIÇÃO DE RENDIMENTOS DO TRABALHO ENTRE CLASSES NAS ÚLTIMAS DÉCADAS}

Resumo

O elevado patamar das desigualdades de rendimentos tem, há muitas décadas, marcado a sociedade brasileira. No período de transição para a democracia, ainda na década de I980, havia a expectativa de que o novo regime seria capaz de enfrentar as principais mazelas do país, a desigualdade sendo uma das principais delas. O presente artigo tem como objetivo verificar se houve redução das desigualdades de renda entre classes no Brasil entre os anos de I995 e 2013, quando dois dos maiores e mais relevantes partidos políticos atuantes no país, o Partido da Social Democracia Brasileira (PSDB) e o Partido dos Trabalhadores (PT), estiveram à frente do governo federal. Para tanto, serão utilizados dados da pesquisa Nacional por Amostras de Domicílios (PNAD-IBGE) referentes ao período abordado.

\section{INEQUALITIES AND THE BRAZILIAN NEW DEMOCRACY: INCOME DISTRIBUTION BETWEEN CLASSES IN RECENT DECADES} ing inequality. This article aims to verify whether there was a reduction of income inequalities between classes in Brazil between I995 and 2013, when two of the largest and most important political parties operating in the country, the Brazilian Social Democracy Party (PSDB) and Workers' Party (PT), headed the federal government. To this end, National Household Sample (PNAD-IBGE) data will be used for the period under study.
Palavras-chave

Desigualdades;

Rendimentos;

Classes;

Democracia;

Brasil.
Keywords

Inequalities;

Income;

Classes;

Democracy;

Brazil. 